\title{
Microwave Accelerated Solvent-Free Synthesis of Flavanones
}

\author{
Gabriel J. Sagrera ${ }^{a}$ and Gustavo A. Seoane ${ }^{*, b}$ \\ ${ }^{a}$ Departamento de Química Orgánica, Facultad de Ciencias and ${ }^{b}$ Facultad de Química, \\ Universidad de la República, C.C.1157, Montevideo, Uruguay
}

\begin{abstract}
A irradiação de chalconas com microondas na ausência de solvente se mostrou um procedimento de "química verde" para a preparação, em bons rendimentos, de flavanonas. Diferentes catalisadores heterogêneos e catalisadores convencionais foram testados usando-se um forno de microondas doméstico. A irradiação de chalconas com 30\% de ácido trifluoroacético, na presença de gel de sílica, levou a formação de onze flavanonas conhecidas e cinco novas, em bons rendimentos.
\end{abstract}

Microwave irradiation of chalcones under solvent-free conditions resulted in a "green-chemistry" procedure for the preparation of flavanones in very good yields. Using an unmodified household microwave oven, different mineral supports and catalysts were tested. By irradiation of chalcones with 30\% TFA over silica gel, eleven known flavanones and five new compounds were prepared in high yields.

Keywords: cyclization, flavanones, Michael addition, microwave, silica gel

\section{Introduction}

Flavanones (2,3-dihydro-2-phenyl-4H-1-benzopyran4-ones and derivatives), 2, a type of flavonoids widely distributed in nature, continue focussing attention due to their ample range of biological activities (hypotensive, antifungal, antibacterial, antitumoral). ${ }^{1}$

The traditional method for the synthesis of flavanones consists of an intramolecular conjugated addition of $o$-hydroxychalcones, $\mathbf{1}$, to the corresponding cyclic carbonylic system. This reaction can be performed using acids, ${ }^{2}$ silica gel, ${ }^{3}$ bases, ${ }^{4,5}$ light,${ }^{6}$ heat,${ }^{7}$ or electrons. ${ }^{8}$

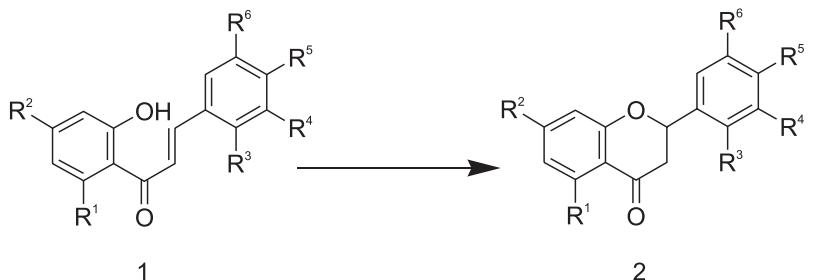

Scheme 1. General structures of $o$-hydroxychalcones, 1, and flavanones, 2.

The acid catalyzed cyclization can be carried out by refluxing the chalcone in acetic acid, or also in ethanol or other suitable solvent, in the presence of an acid catalyst such as $\mathrm{H}_{2} \mathrm{SO}_{4}$ or $\mathrm{H}_{3} \mathrm{PO}_{4} \cdot{ }^{9}$ Basic conditions are seldom used due to decomposition or retroaldol reaction. ${ }^{9}$

* e-mail: gseoane@fq.edu.uy
The corresponding chalcones, in turn, are usually obtained by aldol condensation of $o$-hydroxyacetophenones and benzaldehydes. ${ }^{10}$ However, the conversion of chalcone into flavanone is never complete, the reaction is very slow, and generally proceeds with only moderate yields. Flavanones can also be obtained from precursors other than chalcones, namely by (i) reacting 3-chloro-2,3-dihydro-3nitro-2-phenyl-4H-1-benzopyran-4-ones with tributyltin hydride and 2,2'-azobisisobutyronitrile, ${ }^{11}$ (ii) treating 3bromo-1-phenylprop-2-ynil aryl ethers with mercury(II) trifluoroacetate, ${ }^{12}$ (iii) oxidizing flavan-4-ols, ${ }^{13}$ and (iv) treating 1-(2-hydroxyphenyl)-3-phenyl-propane-1,3-diones with benzaldehydes. ${ }^{14}$ However, these methods receive scarce interest since the precursors are more difficult to obtain than the corresponding chalcones. Since the first reports on chemical applications of microwaves in 1986, ${ }^{15,16}$ this methodology has now become a useful technique for organic synthesis and functional group interconversions. ${ }^{17}$ Synthesis using microwaves have several advantages: shorter reaction times, ease of manipulation, higher yields, and lower costs (they can be solvent-free).

The initial experiments involved reactions in very polar solvents (DMSO, DMF) and sealed containers. The rate enhancement in such reactions is due to rapid superheating of the solvent. ${ }^{15}$

Nowadays the methods are solvent-free, thus irradiation is performed on neat reactants (or in the presence of a 
mineral support). In these cases the rate enhancement in such reactions can be due to simple thermal effects (high localized temperatures may be reached) or specific microwave effects. ${ }^{18}$

In spite of the body of literature about microwaveaccelerated cyclizations, the references on their application to the synthesis of flavonoids are scarce. For example, microwaves have been applied to the synthesis of flavones by a dehydrative cyclization of $o$-hydroxydibenzoylmethanes in clay, ${ }^{19}$ thioflavonoids, ${ }^{20}$ and a new class of mixed flavanone-dihydrochalcone dimers. ${ }^{21}$ Also, Varma et al. described the microwaveinduced cyclization of nitrogen analogues of $2^{\prime}$ hydroxychalcones ( $2^{\prime}$-aminochalcones) to 2-aryl-1,2,3,4tetrahydro-4-quinolones on montmorillonite K-10 clay. ${ }^{22}$

A study on the microwave-induced cyclization of $o$-hydroxychalcones, $\mathbf{1}$, to flavanones, $\mathbf{2}$, on different supports resulted in an equilibrium mixture of $\mathbf{1}$ and $\mathbf{2}$; no significant difference was found between the equilibrium ratio $2: 1$ of microwave-induced or conventional thermal cyclization. ${ }^{3}$

As part of an ongoing project on the synthesis and biological evaluation of flavonoids and other phenolic compounds, $, 923,24$ an easy and reliable method for the preparation of flavanones was needed. We had previously studied the cyclization of 2'-hydroxy-4-methoxychalcone, 3, to 4'-methoxyflavanone, 4, as a model and, among various catalysts, we found that $\mathbf{4}$ was best prepared by refluxing the corresponding chalcone in acetic acid for 72 hours, although in moderate yields (55\%) (Scheme 2). ${ }^{9}$

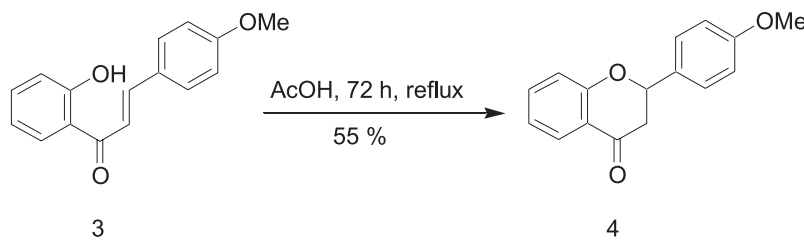

Scheme 2. Cyclization of model chalcone.

\section{Results and Discussion}

In view of the limitations of the existing methods, a study of the microwave-accelerated synthesis of flavanones using an unmodified household microwave oven was undertaken. First of all the cyclization of model chalcone 3 by conventional (thermal) methods of heating was reexamined, widening the set of parameters (Table 1).

In all conditions tested the maximum conversion was reached at approximately 72 hours, even though the final flavanone/ chalcone ratios were quite different. The use of trifluoroacetic acid (TFA) in refluxing chloroform almost doubled the conversion achieved previously in refluxing acetic acid.
Table 1. Flavanone/chalcone ratios in the cyclization of model chalcone $\mathbf{3}$ using conventional methods

\begin{tabular}{|c|c|c|c|c|c|}
\hline \multirow[t]{2}{*}{ Condition } & \multicolumn{4}{|c|}{ Heating time (h) } & \multirow{2}{*}{$\begin{array}{c}\text { Yield of } 4 \\
(\%)\end{array}$} \\
\hline & 24 & 48 & 72 & 96 & \\
\hline $\mathrm{AcOH}^{\mathrm{a}}$ & 2.30 & 2.62 & 2.66 & 2.66 & 69.0 \\
\hline $\begin{array}{l}\mathrm{TFA} / \mathrm{CHCl}_{3}, \\
1 / 4, \mathrm{v} / \mathrm{v}^{\mathrm{a}}\end{array}$ & 4.00 & 4.35 & 4.65 & 4.63 & 78.1 \\
\hline $\begin{array}{l}\text { Silica gel- } \\
\text { toluene a }^{\text {a }}\end{array}$ & 0.59 & 0.80 & 1.12 & 1.11 & 50.1 \\
\hline Silica gel ${ }^{b}$ & 0.40 & 0.72 & 1.00 & 0.95 & 47.5 \\
\hline Neat ${ }^{b}$ & 0.0 & -- & -- & 0.29 & -- \\
\hline $\begin{array}{l}\text { TFA } 30 \%- \\
\text { silica gel, } 50^{\circ} \mathrm{C}\end{array}$ & -- & - & 4.30 & - & -- \\
\hline
\end{tabular}

${ }^{a}$ reflux; ${ }^{b}$ heated at $100{ }^{\circ} \mathrm{C}$ (temperature higher than mp of model chalcone 3).

Then the effect of microwave heating was studied, considering different solid supports and catalysts. After some experimentation the best procedure for the irradiation is described as follows. The reaction mixtures were heated successively for 3 min periods followed by a 5 min cooling interval between irradiations.

This method was designed to avoid overheating of reactants, according to Varma et al. ${ }^{25}$ since the unmodified household microwave oven lacks the special attributes of commercial reactors in terms of power and temperature control. In addition, because a standard household microwave oven was used, a experiment to test the homogeneity of the irradiating field was conducted. To this end, in the irradiation of model chalcone $\mathbf{3}$, three samples were withdrawn from the reaction test tube in each run, taken at different depths (top, middle, bottom) of the catalyst's bed. The flavanone/chalcone ratio was analyzed by NMR and, in all cases, the determined ratios fell within $5 \%$, thus indicating an acceptable field homogeneity.

In the following experiments, using different solid supports (Table 2) and catalysts (Table 3), the flavanone/ chalcone ratio was determined by NMR analysis. Except when otherwise stated, the crude reaction mixtures contained only flavanone and unreacted chalcone.

Tables 2 and 3 show that the maximum conversion is always reached between 6 and $9 \mathrm{~min}$, even though the final flavanone/chalcone ratio spans widely.

Table 2. Flavanone/chalcone ratios in the cyclization of model chalcone 3 using different mineral supports.

\begin{tabular}{lcccc}
\hline Mineral support & \multicolumn{4}{c}{ Irradiation time (min) } \\
\hline Silica gel & 3 & 6 & 9 & 12 \\
K-10 clay & 0.05 & 0.2 & 0.35 & 0.37 \\
Neutral alumina & 0.0 & 0.1 & 0.25 & 0.25 \\
Acidic alumina & $*$ & - & - & - \\
Basic alumina & $*$ & - & - & -
\end{tabular}

* complex mixtures were formed. 
Table 3. Flavanone/chalcone ratios in the cyclization of model chalcone $\mathbf{3}$ using different catalysts and silica gel as mineral support

\begin{tabular}{lcccc}
\hline Catalyst & \multicolumn{4}{c}{ Irradiation time (min) } \\
\hline & 3 & 6 & 9 & 12 \\
Silica gel & 0.05 & 0.20 & 0.35 & 0.37 \\
AcOH 30\% a & 1.23 & 1.88 & 2.55 & $*$ \\
TFA 30\% a & 2.54 & 3.75 & 4.78 & $3.80^{*}$ \\
p-TsOH 30\% a & $0.16^{*}$ & - & - & - \\
\hline a 30\% is referred to percentage $\mathrm{m} / \mathrm{m}$ over silica gel; * other products \\
were formed.
\end{tabular}

Regarding the mineral support, only silica gel and montmorillonite K-10 clay afforded clean conversion to flavanones, whereas all types of alumina tested (neutral, basic or acidic) resulted in complex mixtures of chalcone, flavanone, flavone and retroaldol products after irradiation. Montmorillonite K-10 clay was less effective to catalize the cyclization, producing lower flavanone/chalcone ratios (maximum ratio: 0.25 at 12 minutes).

After choosing silica gel as the mineral support, different acid catalysts were tested (Table 3). Inspection of data showed that the conversion increases with the acidity of the catalyst used. Consequently, the use of TFA resulted in high flavanone/chalcone ratios, even after $3 \mathrm{~min}$ of irradiation. In this case, at $12 \mathrm{~min}$ some decomposition took place. From these results it was concluded that the best method is irradiation of chalcone with 30\% TFA over silica gel for 3 periods of $3 \mathrm{~min}$.
An acceleration of the reaction rate on the order of 500-fold increase is observed when microwaves are used. Almost the same flavanone/chalcone ratio is obtained at 72 hours with clasical methods (Table 1) and at $9 \mathrm{~min}$ using microwave heating (Table 3).

Utilizing these conditions a number of flavanones was prepared (Table 4). The present technique considerably reduces the long reaction time usually encountered in traditional flavanone synthesis and affords the desired product in very good yields.

The method is applicable to chalcones containing an ample range of substituents, namely $\mathrm{OH}, \mathrm{OR}(\mathrm{R}=$ methyl, $n$-butyl, $n$-hexyl, $n$-nonyl), $\mathrm{Br}, \mathrm{NO}_{2}$, and $\mathrm{N}\left(\mathrm{CH}_{3}\right)_{2}$. The flavanone to chalcone ratio and the flavanone isolated yields are consistently high along Table 4 and compare favorably to those obtained by classical procedures.

The reaction is very clean and no other products are seen, except for entry $\mathrm{k}$ where, even after $3 \mathrm{~min}$, partial debenzylation takes place giving a mixture of 4'-benzyloxyflavanone (expected product), 4'-hydroxyflavanone (deprotected product) and unreacted chalcone in a 2.7/1/1 ratio. All compounds gave satisfactory spectroscopic and analytical data.

In conclusion, in this work we describe a solvent-free, simple, rapid and high yielding method for the synthesis of flavanones using an unmodified conventional microwave oven.

Table 4. Flavanones obtained by microwave irradiation ${ }^{\mathrm{a}}$<smiles>[R]c1cc([R])c(C(=O)/C=C/c2cc([R])c([R])c([R])c2[R])c(O)c1</smiles>

\begin{tabular}{ccccccccc}
\hline Entry & $\mathrm{R}_{1}$ & $\mathrm{R}_{2}$ & $\mathrm{R}_{3}$ & $\mathrm{R}_{4}$ & $\mathrm{R}_{5}$ & $\mathrm{R}_{6}$ & Ratio 2/1 & Isolated yields (\%) \\
\hline $\mathrm{a}$ & $\mathrm{H}$ & $\mathrm{H}$ & $\mathrm{H}$ & $\mathrm{H}$ & $\mathrm{H}$ & $\mathrm{H}$ & 5.36 & 80 \\
$\mathrm{~b}$ & $\mathrm{H}$ & $\mathrm{H}$ & $\mathrm{H}$ & $\mathrm{H}$ & $\mathrm{OMe}$ & $\mathrm{H}$ & 4.78 & 79 \\
$\mathrm{c}$ & $\mathrm{H}$ & $\mathrm{H}$ & $\mathrm{H}$ & $\mathrm{H}$ & $\mathrm{OH}$ & $\mathrm{H}$ & 4.72 & 77 \\
$\mathrm{~d}$ & $\mathrm{H}$ & $\mathrm{H}$ & $\mathrm{H}$ & $\mathrm{H}$ & $\mathrm{NO}_{2}$ & $\mathrm{H}$ & 4.26 & 76 \\
$\mathrm{e}$ & $\mathrm{H}$ & $\mathrm{H}$ & $\mathrm{H}$ & $\mathrm{H}$ & $\mathrm{NMe}_{2}$ & $\mathrm{H}$ & 3.70 & 69 \\
$\mathrm{f}$ & $\mathrm{H}$ & $\mathrm{H}$ & $\mathrm{H}$ & $\mathrm{OMe}^{2}$ & $\mathrm{OMe}$ & $\mathrm{H}$ & 4.70 & 78 \\
$\mathrm{~g}$ & $\mathrm{H}$ & $\mathrm{H}$ & $\mathrm{H}$ & $-\mathrm{OCH}_{2} \mathrm{O}-$ & & $\mathrm{H}$ & 4.70 & 77 \\
$\mathrm{~h}$ & $\mathrm{OMe}$ & $\mathrm{OMe}$ & $\mathrm{H}$ & $\mathrm{OMe}$ & $\mathrm{OMe}$ & $\mathrm{H}$ & 4.62 & 73 \\
$\mathrm{i}$ & $\mathrm{OMe}$ & $\mathrm{OMe}$ & $\mathrm{H}$ & $\mathrm{H}$ & $\mathrm{OMe}$ & $\mathrm{H}$ & 4.60 & 75 \\
$\mathrm{j}$ & $\mathrm{H}$ & $\mathrm{H}$ & $\mathrm{OMe}$ & $\mathrm{H}$ & $\mathrm{H}$ & $\mathrm{OMe}$ & 4.65 & 73 \\
$\mathrm{k}$ & $\mathrm{H}$ & $\mathrm{H}$ & $\mathrm{H}$ & $\mathrm{H}$ & $\mathrm{OBn}$ & $\mathrm{H}$ & $*$ & 76 \\
1 & $\mathrm{H}$ & $\mathrm{n}-\mathrm{C}_{4} \mathrm{H}_{9} \mathrm{O}$ & $\mathrm{H}$ & $\mathrm{H}$ & $\mathrm{n}_{4} \mathrm{C}_{4} \mathrm{H}_{9} \mathrm{O}$ & $\mathrm{H}$ & 4.62 & 76 \\
$\mathrm{~m}$ & $\mathrm{H}$ & $\mathrm{H}$ & $\mathrm{Br}$ & $\mathrm{H}$ & $\mathrm{H}$ & $\mathrm{H}$ & 4.68 & 76 \\
$\mathrm{n}$ & $\mathrm{H}$ & $\mathrm{H}$ & $\mathrm{H}$ & $\mathrm{H}$ & $\mathrm{n}-\mathrm{C}_{6} \mathrm{H}_{13} \mathrm{O}$ & $\mathrm{H}$ & 4.64 & 77 \\
$\mathrm{o}$ & $\mathrm{H}$ & $\mathrm{H}$ & $\mathrm{H}$ & $\mathrm{H}$ & $\mathrm{n}-\mathrm{C}_{9} \mathrm{H}_{19} \mathrm{O}$ & $\mathrm{H}$ & 4.67 & 75 \\
$\mathrm{p}$ & $\mathrm{OMe}$ & $\mathrm{OMe}$ & $\mathrm{Br}$ & $\mathrm{H}$ & $\mathrm{H}$ & $\mathrm{H}$ & 4.61 & 76 \\
\hline
\end{tabular}

${ }^{\mathrm{a}}$ Entry a-k : known compounds, $1-\mathrm{p}:$ new compounds; * see text. 


\section{Experimental}

${ }^{1} \mathrm{H}$ and ${ }^{13} \mathrm{C}$ NMR spectra were recorded in $\mathrm{CDCl}_{3}$ solutions on a Bruker DPX-400 spectrometer (at $400 \mathrm{MHz}$ and 100 $\mathrm{MHz}$, respectively) with TMS as the internal reference. Chemical shifts $(\delta)$ are reported in ppm and coupling constants $(J)$ are given in Hz. Mass spectra were recorded on a Shimadzu GC-MS QP 1100 EX spectrometer at $70 \mathrm{eV}$. TLC was carried out on Alugram ${ }^{\circledast} \mathrm{Sil} \mathrm{G/UV}{ }_{254}$ on polyester plates using different solvent systems. Melting points were determined using a Gallenkamp capillary melting point apparatus and are uncorrected. IR spectra were recorded on a Bomen, Hartman \& Braun FTIR spectrophotometer, using $\mathrm{KBr}$ tablets; the frequency being expressed in $\mathrm{cm}^{-1}$. Column chromatography (CC) was carried out on silica gel (Merck, 60-230 mesh). All solvents were dried and distilled prior to use.

A simple household microwave oven equipped with a turntable was used for microwave heating $(2450 \mathrm{MHz})$ at full power. The nominal (output) power indicated in the equipment is $800 \mathrm{~W}$. The actual full power was determined to be $600 \mathrm{~W}$ according to the procedure described by Barboza. ${ }^{26}$

The mineral supports used in the different experiments were: silica gel for column chromatography (Merck, 60230 mesh); Aluminium oxide for chromatography, Fluka type 507C neutral, 100-125 mesh, pH $7.0 \pm 0.5$ (neutral alumina); Aluminium oxide for chromatography, Fluka type 5016A basic, pH $9.5 \pm 0.3$ (basic alumina); Aluminium oxide for chromatography, Fluka type $504 \mathrm{C}$ acidic; $\mathrm{pH}$ $4.5 \pm 0.3$ (acidic alumina), Montmorillonite K-10 clay, surface $200 \mathrm{~m}^{2} / \mathrm{g}$, from Fluka.

\section{Procedure for the optimization of the cyclization reaction}

Model chalcone (2'-hydroxy-4-methoxychalcone, $25 \mathrm{mg}$, $0.1 \mathrm{mmol}$ ) is dissolved in $5 \mathrm{~mL}$ of dry $\mathrm{CH}_{2} \mathrm{Cl}_{2}$ and the catalyst and mineral support were added (see Tables 2-3). The suspension is evaporated under vacuum and the resulting powder is placed in a loosely stoppered test tube $(1.2 \mathrm{~cm}$ i.d.

In order to irradiate the reaction mixture, the test tube is placed vertically in the center of the microwave oven besides a vial with ice $(20 \mathrm{~g})$ to control irradiation.

In all cases the reaction mixtures are irradiated for 4 successive periods of $3 \mathrm{~min}$ each with an interval of $5 \mathrm{~min}$ for cooling. During the cooling interval the test tube is withdrawn from the oven.

The reaction was monitored by TLC and NMR. After every irradiation (it means: 3, 69 and 12 minutes), the solid is homogenized, and an alicuot of the solid is taken with a Pasteur pipette. Each alicuot was extracted with ethyl acetate $(3 \times 10 \mathrm{~mL})$. The organic layer was washed with water, separated and dried over $\mathrm{Na}_{2} \mathrm{SO}_{4}$. The solvent was removed under vacuum and flavanone/chalcone ratios were determined by NMR. The mixture was purified by $\mathrm{CC}$ (silica gel) using hexane as initial eluent followed by $\mathrm{CH}_{2} \mathrm{Cl}_{2} /$ hexane $(1: 1 \mathrm{v} / \mathrm{v})$.

\section{Homogeneity of the field}

A loosely stoppered test tube containing the reaction mixture of model chalcone is placed vertically in the center of the microwave oven besides a vial with ice $(20 \mathrm{~g})$, and irradiated for 3 successive periods of 3 min with a cooling interval of $5 \mathrm{~min}$ between irradiations. After this, three samples are taken from different depths (top, middle, bottom) of the tube, and extracted with ethyl acetate $(3 \times 15 \mathrm{~mL})$. The organic layer was washed with water, separated and dried over $\mathrm{Na}_{2} \mathrm{SO}_{4}$. The solvent was removed under vacuum and flavanone/ chalcone ratios were determined by NMR. Flavanone/ chalcone ratios consistently gave results within $5 \%$.

\section{General procedure for the synthesis of flavanones $2 a-2 p$}

To a solution of desired chalcone $(0.1 \mathrm{mmol}$ in $5 \mathrm{~mL}$ of dry $\mathrm{CH}_{2} \mathrm{Cl}_{2}$ ), $0.2 \mathrm{~mL}$ of TFA and $1 \mathrm{~g}$ of silica gel was added. The mixture is evaporated under vacuum and the resulting powder is poured into a loosely stoppered test tube. The tube is placed vertically in the center of the microwave oven besides a vial with ice ( $20 \mathrm{~g})$, and irradiated for 3 successive periods of $3 \mathrm{~min}$ with cooling intervals of $5 \mathrm{~min}$. After irradiation is finished, the solid mixture is extracted with ethyl acetate $(3 \times 15 \mathrm{~mL})$ and the organic layer was washed with water, separated and dried over $\mathrm{Na}_{2} \mathrm{SO}_{4}$. The solvent was removed under vacuum and flavanone/chalcone ratios were determined by NMR. The mixture was purified by $\mathrm{CC}$ (silica gel) using hexane as initial eluent followed by $\mathrm{CH}_{2} \mathrm{Cl}_{2}$ /hexane $(1: 1 \mathrm{v} / \mathrm{v})$ or ethyl acetate/hexane $(1: 1 \mathrm{v} / \mathrm{v})$.

\section{Spectroscopic data of new compounds}

Note : Assignments of $\mathrm{H}$ and $\mathrm{C}$ are given according to flavanone numbering (in all cases $\mathrm{C}=\mathrm{O}$ means $\mathrm{C} 4$ ):

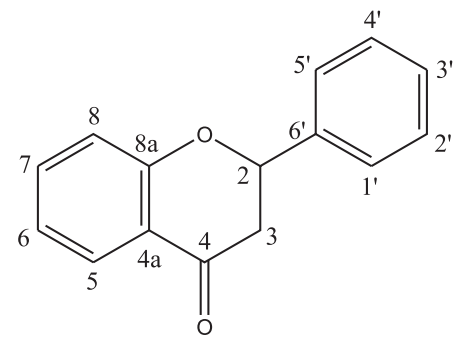




\section{7,4'-dibutyloxyflavanone (2l)}

Light yellow solid; mp $86-88^{\circ} \mathrm{C} .{ }^{1} \mathrm{H}$ NMR $\left(\mathrm{CDCl}_{3}\right): \delta$ $7.87\left(\mathrm{~d}, 1 \mathrm{H}, J\right.$ 8.8, $\left.\mathrm{H}_{5}\right), 7.42-7.38\left(\mathrm{~m}, 2 \mathrm{H}, \mathrm{H}_{2},+\mathrm{H}_{6}\right), 6.98-$ $6.94\left(\mathrm{~m}, 2 \mathrm{H}, \mathrm{H}_{3}{ }^{\prime}+\mathrm{H}_{5}{ }^{\prime}\right), 6.61\left(\mathrm{dd}, 1 \mathrm{H}, J_{1} 8.8, J_{2} 2.3, \mathrm{H}_{6}\right), 6.48$ $\left(\mathrm{d}, 1 \mathrm{H}, J 2.3, \mathrm{H}_{8}\right), 5.42\left(\mathrm{dd}, 1 \mathrm{H}, J_{1} 13.2, J_{2} 2.8, \mathrm{H}_{2}\right), 4.02-$ $3.98\left(\mathrm{~m}, 4 \mathrm{H},-\mathrm{OCH}_{2}{ }^{-}+-\mathrm{OCH}_{2}-\right), 3.06\left(\mathrm{dd}, 1 \mathrm{H}, J_{1} 16.8, J_{2}\right.$ $\left.13.2, \mathrm{H}_{3 \mathrm{ax}}\right), 2.81\left(\mathrm{dd}, 1 \mathrm{H}, J_{1} 16.8, J_{2} 2.8, \mathrm{H}_{3 \mathrm{eq}}\right), 1.81-1.76(\mathrm{~m}$, $\left.4 \mathrm{H},-\mathrm{OCH}_{2} \mathrm{C}_{2}-+-\mathrm{OCH}_{2} \mathrm{CH}_{2}-\right), 1.53-1.48\left(\mathrm{~m}, 4 \mathrm{H}, \mathrm{CH}_{3}-\mathrm{CH}_{2}-\right.$ $\left.+\mathrm{CH}_{3}-\mathrm{CH}_{2}-\right), 1.02-0.97\left(\mathrm{~m}, 6 \mathrm{H}, \mathrm{CH}_{3}+\mathrm{CH}_{3}\right) \cdot{ }^{13} \mathrm{C} \mathrm{NMR}$ $\left(\mathrm{CDCl}_{3}\right) \delta 190.87(\mathrm{C}=\mathrm{O}), 165.81(8 \mathrm{a}), 163.63$ (7), 159.56 (4'), 130.67 (1'), $128.66\left(2^{\prime}+6\right.$ '), 127.67 (5), 114.76 (4a), $114.64\left(3^{\prime}+5^{\prime}\right), 110.59(6), 101.34(8), 79.75$ (2), 68.17 ($\left.\mathrm{OCH}_{2}\right), 67.82\left(-\mathrm{OCH}_{2}\right), 44.11$ (3), $31.26\left(-\mathrm{OCH}_{2}-\mathrm{CH}_{2}-\right)$, $30.98\left(-\mathrm{OCH}_{2}-\mathrm{CH}_{2}-\right), 19.22\left(\mathrm{CH}_{3}-\mathrm{CH}_{2}\right), 19.13\left(\mathrm{CH}_{3}-\mathrm{CH}_{2}\right)$, $13.79\left(\mathrm{CH}_{3}\right), 13.72\left(\mathrm{CH}_{3}\right)$. MS (EI) $\mathrm{m} / 2$ (\%) $368(100.0)$, 367 (61.4), 311 (21.5), 255 (15.7), 219 (18.8), 163 (78.7), 147 (10.5), 120 (65.8), 57 (11.3), 41 (23.2). IR (KBr) $v_{\max }$ ' $\mathrm{cm}^{-1}: 1684,1609,1515$. Anal. Calc. for $\mathrm{C}_{23} \mathrm{H}_{28} \mathrm{O}_{4}: \mathrm{C}, 75.00$; H, 7.61\%. Found: C, 74.91; H, 7.66\%.

\section{2'-Bromoflavanone (2m)}

Light yellow solid; mp 141-144 ${ }^{\circ} \mathrm{C} .{ }^{1} \mathrm{H}$ NMR $\left(\mathrm{CDCl}_{3}\right) \delta$ $7.96\left(\mathrm{dd}, 1 \mathrm{H}, J_{1} 7.8, J_{2} 1.7, \mathrm{H}_{5}\right), 7.75\left(\mathrm{dd}, 1 \mathrm{H}, J_{1} 7.8, J_{2} 1.5, \mathrm{H}_{6}{ }^{\prime}\right)$, $7.60\left(\mathrm{dd}, 1 \mathrm{H}, J_{1} 8.0, J_{2} 1.1, \mathrm{H}_{3}{ }^{\prime}\right), 7.53\left(\mathrm{ddd}, 1 \mathrm{H}, J_{1} 8.4, J_{2} 7.1, J_{3}\right.$ $\left.1.7, \mathrm{H}_{7}\right), 7.44$ (ddd, $\left.1 \mathrm{H}, J_{1} 7.8, J_{2} 6.3, J_{3} 1.1, \mathrm{H}_{5}{ }^{\prime}\right), 7.24$ (ddd, $\left.1 \mathrm{H}, J_{1} 8.0, J_{2} 6.3, J_{3} 1.5, \mathrm{H}_{4}{ }^{\prime}\right), 7.10-7.05\left(\mathrm{~m}, 2 \mathrm{H}, \mathrm{H}_{6}+\mathrm{H}_{8}\right), 5.83$ $\left(\mathrm{dd}, 1 \mathrm{H}, J_{1} 13.5, J_{2} 2.7, \mathrm{H}_{2}\right), 3.06\left(\mathrm{dd}, 1 \mathrm{H}, J_{1} 16.9, J_{2} 2.7, \mathrm{H}_{3 \mathrm{eq}}\right.$ ), $2.86\left(\mathrm{dd}, 1 \mathrm{H}, J_{1} 16.9, J_{2} 13.5, \mathrm{H}_{3 \mathrm{ax}}\right){ }^{13} \mathrm{CNMR}\left(\mathrm{CDCl}_{3}\right) \delta 191.42$ $(\mathrm{C}=\mathrm{O}), 161.53$ (8a), $138.36\left(1^{\prime}\right), 136.18(7), 133.02\left(3^{\prime}\right), 129.92$ (4'), 128.05 (5'), 127.49 (6'), 127.17 (5), 121.84 (6'), 121.50 (2' or 4a), 121.00 (2' or 4a), 118.08 (8), 78.76 (2), 43.60 (3). MS (EI) $m / z(\%) 304$ (15.1), 303 (10.6), 302 (15.7), 301 (8.4), 224 (16.2), 223 (100.0), 222 (12.4), 147 (41.3), 121 (23.2), 120 (14.5), 102 (17.7). IR (KBr) $v_{\max } / \mathrm{cm}^{-1}: 1694,1606,1474$. Anal. Calc. for $\mathrm{C}_{15} \mathrm{H}_{11} \mathrm{O}_{2} \mathrm{Br}$ : C, 59.40; H, 3.63\%. Found: C, $59.61 ; \mathrm{H}, 3.96 \%$.

\section{4'-Hexyloxyflavanone (2n)}

Light yellow solid; mp 77-79 ${ }^{\circ} \mathrm{C} .{ }^{1} \mathrm{H}$ NMR $\left(\mathrm{CDCl}_{3}\right) \delta$ $7.94\left(\mathrm{dd}, 1 \mathrm{H}, J_{1} 7.7, J_{2} 1.7, \mathrm{H}_{5}\right), 7.50\left(\mathrm{ddd}, 1 \mathrm{H}, J_{1} \approx J_{2} \approx 7.8\right.$, $\left.J_{3} 1.7 ; \mathrm{H}_{7}\right), 7.44-7.37\left(\mathrm{~m}, 2 \mathrm{H}, \mathrm{H}_{2}{ }^{\prime}+\mathrm{H}_{6}{ }^{\prime}\right), 7.08-7.01(\mathrm{~m}, 2 \mathrm{H}$, $\left.\mathrm{H}_{6}+\mathrm{H}_{8}\right), 6.98-6.92\left(\mathrm{~m}, 2 \mathrm{H}, \mathrm{H}_{3}{ }^{\prime}+\mathrm{H}_{5}{ }^{\prime}\right), 5.42\left(\mathrm{dd}, 1 \mathrm{H}, J_{1}\right.$ $\left.13.3, J_{2} 2.7, \mathrm{H}_{2}\right), 3.98\left(\mathrm{t}, 2 \mathrm{H}, J 6.6,-\mathrm{OCH}_{2}-\right), 3.11\left(\mathrm{dd}, 1 \mathrm{H}, J_{1}\right.$ $\left.16.8, J_{2} 13.3, \mathrm{H}_{3 \mathrm{ax}}\right), 2.86\left(\mathrm{dd}, 1 \mathrm{H}, J_{1} 16.8, J_{2} 2.7, \mathrm{H}_{3 \mathrm{eq}}\right), 1.83-$ $1.75\left(\mathrm{~m}, 2 \mathrm{H},-\mathrm{OCH}_{2}-\mathrm{C}_{2}-\right), 1.51-1.41\left(\mathrm{~m}, 2 \mathrm{H},-\mathrm{OCH}_{2}-\mathrm{CH}_{2}-\right.$ $\left.\mathrm{C}_{2}\right), 1.40-1.23\left(\mathrm{~m}, 4 \mathrm{H},-\mathrm{C}_{2}-\mathrm{C}_{2}-\mathrm{CH}_{3}\right), 0.95-0.80(\mathrm{~m}, 3 \mathrm{H}$, $\left.\mathrm{CH}_{3}\right) .{ }^{13} \mathrm{C}$ NMR $\left(\mathrm{CDCl}_{3}\right) \delta 192.20(\mathrm{C}=\mathrm{O}), 161.69(8 \mathrm{a})$, 159.61 (4'), 136.12 (7), $130.55\left(1^{\prime}\right), 127.69\left(2^{\prime}+6^{\prime}\right), 127.04$
(5), 121.49 (6), 120.90 (4a), 118.14 (8), $114.80\left(3^{\prime}+5^{\prime}\right)$, 79.42 (2), $68.17\left(-\mathrm{OCH}_{2}-\right), 44.48$ (3), $31.56\left(-\mathrm{CH}_{2}-\mathrm{CH}_{2}-\right.$ $\left.\mathrm{CH}_{3}\right), 29.12\left(-\mathrm{OCH}_{2}-\mathrm{CH}_{2}-\right), 25.70\left(-\mathrm{CH}_{2}-\mathrm{CH}_{2}-\mathrm{CH}_{2}-\mathrm{CH}_{3}\right)$, $22.58\left(-\mathrm{CH}_{2}-\mathrm{CH}_{3}\right), 14.00\left(\mathrm{CH}_{3}\right)$. MS (EI) $\mathrm{m} / z(\%) 324(100.0)$, 323 (66.1), 240 (26.7), 239 (88.2), 223 (30.6), 204 (18.7), 121 (91.6), 120 (96.3), 71 (11.7), 57 (24.0), 43 (52.1), 41 (31.4). IR (KBr) $v_{\max } / \mathrm{cm}^{-1}: 1692,1608,1514$. Anal. Calc. for $\mathrm{C}_{21} \mathrm{H}_{24} \mathrm{O}_{3}: \mathrm{C}, 77.77 ; \mathrm{H}, 7.41 \%$. Found: $\mathrm{C}, 77.37 ; \mathrm{H}$, $7.11 \%$.

\section{4'-Nonyloxyflavanone (2o)}

Light yellow solid; mp 75-78 ${ }^{\circ} \mathrm{C} .{ }^{1} \mathrm{H}$ NMR $\left(\mathrm{CDCl}_{3}\right) \delta$ $7.93\left(\mathrm{dd}, 1 \mathrm{H}, J_{1} 7.7, J_{2} 1.7, \mathrm{H}_{5}\right), 7.50\left(\mathrm{ddd}, 1 \mathrm{H}, J_{1} \approx J_{2} \approx 7.8\right.$, $\left.J_{3} 1.7 ; \mathrm{H}_{7}\right), 7.42-7.34\left(\mathrm{~m}, 2 \mathrm{H}, \mathrm{H}_{2}{ }^{\prime}+\mathrm{H}_{6}{ }^{\prime}\right), 7.06-6.99(\mathrm{~m}$, $\left.2 \mathrm{H}, \mathrm{H}_{6}+\mathrm{H}_{8}\right), 6.96-6.90\left(\mathrm{~m}, 2 \mathrm{H}, \mathrm{H}_{3}{ }^{\prime}+\mathrm{H}_{5}{ }^{\prime}\right), 5.43\left(\mathrm{dd}, 1 \mathrm{H}, J_{1}\right.$ $\left.13.3, J_{2} 2.7, \mathrm{H}_{2}\right), 3.97\left(\mathrm{t}, 2 \mathrm{H}, J 6.5,-\mathrm{OCH}_{2}-\right), 3.11\left(\mathrm{dd}, 1 \mathrm{H}, J_{1}\right.$ $\left.16.8, J_{2} 13.3, \mathrm{H}_{3 \mathrm{ax}}\right), 2.86\left(\mathrm{dd}, 1 \mathrm{H}, J_{1} 16.8, J_{2} 2.7, \mathrm{H}_{3 \mathrm{eq}}\right), 1.82-$ $1.75\left(\mathrm{~m}, 2 \mathrm{H},-\mathrm{OCH}_{2}-\mathrm{C}_{2}-\right), 1.46-1.42\left(\mathrm{~m}, 2 \mathrm{H},-\mathrm{OCH}_{2}-\mathrm{CH}_{2}-\right.$ $\left.\mathrm{C}_{2}-\right), 1.28-1.24\left(\mathrm{~m}, 10 \mathrm{H},-\underline{\mathrm{C}}_{2}-\underline{\mathrm{CH}}_{2}-\mathrm{C}_{2}-\mathrm{C}_{2}-\mathrm{C}_{2}-\mathrm{CH}_{3}\right)$, $0.90-0.87\left(\mathrm{~m}, 3 \mathrm{H}, \mathrm{CH}_{3}\right) .{ }^{13} \mathrm{C} \mathrm{NMR}\left(\mathrm{CDCl}_{3}\right) \delta 192.25(\mathrm{C}=\mathrm{O})$, 161.60 (8a), 159.61 (4'), 136.12 (7), 130.54 (1'), 127.68 $\left(2^{\prime}+6^{\prime}\right), 127.04(5), 121.49(6), 120.96$ (4 a), $118.15(8)$, $114.80\left(3^{\prime}+5^{\prime}\right), 79.42(2), 68.18\left(-\mathrm{OCH}_{2}-\right), 44.48$ (3), 31.87 $\left(-\mathrm{CH}_{2}-\mathrm{CH}_{2}-\mathrm{CH}_{3}\right), 29.69\left(-\mathrm{CH}_{2}-\mathrm{CH}_{2}-\mathrm{CH}_{2}-\mathrm{CH}_{3}\right), 29.52$ ($\left.\mathrm{OCH}_{2}-\mathrm{CH}_{2}-\mathrm{CH}_{2}-\underline{\mathrm{CH}}_{2}-\right), 29.38\left(-\mathrm{OCH}_{2}-\mathrm{CH}_{2}-\right), 29.23\left(-\mathrm{CH}_{2}-\right.$ $\left.\left(\mathrm{CH}_{2}\right)_{3}-\mathrm{CH}_{3}\right), 26.03\left(-\mathrm{OCH}_{2}-\mathrm{CH}_{2}-\mathrm{CH}_{2}-\right), 22.66\left(-\mathrm{CH}_{2}-\mathrm{CH}_{3}\right)$, $14.08\left(\mathrm{CH}_{3}\right)$. MS (EI) $\mathrm{m} / \mathrm{z}(\%) 366$ (100.0), 365 (68.0), 240 (25.1), 239 (72.9), 233 (25.1), 223 (23.1), 121 (66.1), 120 (69.6), 119 (20.4), 43 (35.5), 41 (23.9). IR (KBr) $v_{\max } / \mathrm{cm}^{-1}$ : 1694, 1605, 1489. Anal. Calc. for $\mathrm{C}_{24} \mathrm{H}_{30} \mathrm{O}_{3}: \mathrm{C}, 78.68 ; \mathrm{H}$, $8.20 \%$. Found: C, $78.74 ; \mathrm{H}, 8.28 \%$.

\section{5,7-Dimethoxy-2'-bromoflavanone (2p)}

Light yellow solid; mp 157-159 ${ }^{\circ} \mathrm{C} .{ }^{1} \mathrm{H}$ NMR $\left(\mathrm{CDCl}_{3}\right)$ $\delta 7.68\left(\mathrm{dd}, 1 \mathrm{H}, J_{1} 7.8, J_{2} 1.5, \mathrm{H}_{6}{ }^{\prime}\right), 7.58\left(\mathrm{dd}, 1 \mathrm{H}, J_{1} 8.0, J_{2}\right.$ $\left.1.0, \mathrm{H}_{3}{ }^{\prime}\right), 7.41$ (ddd, $\left.1 \mathrm{H}, J_{1} 7.8, J_{2} 6.3 ; J_{3} 1.0, \mathrm{H}_{5}{ }^{\prime}\right), 7.22$ (ddd, $\left.1 \mathrm{H}, J_{1} 8.0, J_{2} 6.3 ; J_{3} 1.5, \mathrm{H}_{4}{ }^{\prime}\right), 6.17\left(\mathrm{~d}, 1 \mathrm{H}, J 2.2, \mathrm{H}_{6}\right)$, $6.12\left(\mathrm{~d}, 1 \mathrm{H}, J 2.2, \mathrm{H}_{8}\right), 5.76\left(\mathrm{dd}, 1 \mathrm{H}, J_{1} 13.2, J_{2} 2.9, \mathrm{H}_{2}\right), 3.91$ (s, 3H, OMe), 3.83 (s, 3H, OMe), 2.96 (dd, 1H, $J_{1} 16.6, J_{2}$ $\left.2.9, \mathrm{H}_{3 \mathrm{eq}}\right), 2.80\left(\mathrm{dd}, 1 \mathrm{H}, J_{1} 16.6, J_{2} 13.2, \mathrm{H}_{3 \mathrm{ax}}\right) \cdot{ }^{13} \mathrm{C} \mathrm{NMR}$ $\left(\mathrm{CDCl}_{3}\right) \delta 188.69(\mathrm{CO}), 166.04$ (8 a ), 165.02 (5), 162.46 (7), 138.35 (1'), 133.04 (3'), 129.85 (2'), 127.99 (6'), 127.40 (5'), 121.69 (4 a), 106.12 (4'), 93.65 (8), 93.41 (6), 78.43 (2), $56.19(\mathrm{OMe}), 55.64(\mathrm{OMe}), 44.57$ (3). MS (EI) $\mathrm{m} / \mathrm{z}(\%)$ 364 (21.2), 363 (14.5), 362 (21.2), 361 (10.8), 207 (100.0), 181 (39.6), 102 (31.6), 101 (17.5), 95 (16.1), 76 (11.2), 75 (18.5), 69 (25.3). IR (KBr) $v_{\max } / \mathrm{cm}^{-1}: 1674,1608,1489$. Anal. Calc. for $\mathrm{C}_{17} \mathrm{H}_{15} \mathrm{O}_{4} \mathrm{Br}$ : C, 56.20; H, 4.13\%. Found: $\mathrm{C}$, $56.14 ; \mathrm{H}, 4.81 \%$. 


\section{Supplementary Information}

Supplementary data are available free of charge as PDF file at http://jbcs.sbq.org.br.

\section{Acknowledgments}

The assistance of Mr. Horacio Pezaroglo for recording NMR spectra is kindly acknowledged.

\section{References}

1. Wang, Y.; Tan, W.; Li, W. Z.; Li, Y.; J. Nat. Prod. 2001, 64, 196.

2. Cheng, P.L.; Fournari, P.; Tirouflet, J.; Bull. Soc. Chim. France 1963, 2248.

3. Sangwan, N.K.; Varma, B.S.; Dhindsa, K.S.; Chem. Ind. (London) 1984, 271.

4. Keane, D.D.; Marathe, K.G.; O’Sullivan W.I.; Philbin, E.M.; Simons, R.M.; Teague, P.C.; J. Org. Chem. 1970, 35, 2286.

5. Löwenbein, A.; Ber. 1924, 57B, 1515.

6. Pandey, G.; Krishna, A.; Kumaraswamy, G.; Tetrahedron Lett. 1987, 28, 4615.

7. Goud, B.S.; Panneerselvam, K.; Zacharias, D.E.; Desiraju, G.R.; J. Chem. Soc. Perkin Trans. 2 1995, 325.

8. Sanicanin, Z.; Tabakovic, I.; Tetrahedron Lett. 1986, 27, 407.

9. Sagrera, G.; López, V.; Pandolfi, E.; Seoane, G.; Eicher, T.; Información Tecnológica 1998, 9, 11.
10. Stout, G.H.; Stout, V.F.; Tetrahedron 1961, 14, 296.

11. Dauzonne, D.; Monneret, C.; Synthesis 1997, 1305.

12. Subramanian, R.S.; Balasubramanian, K.K.; J. Chem. Soc., Chem. Commun. 1990, 1469.

13. Bhatia, V.K., Krishnamurty, H.G.; Madhav, R.; Seshadri, T.R.; Tetrahedron Lett. 1968, 9, 3859.

14. Joglekar, S.J.; Samant, S.D.; Tetrahedron Lett. 1988, 29, 241.

15. Gedye, R.; Smith, F.; Westaway, K.; Ali, H.; Baldisera, L.; Laberge, L.; Rousell, J.; Tetrahedron Lett. 1986, 27, 279.

16. Giguere, R.J.; Bray, T.L.; Duncan, S.M.; Tetrahedron Lett. 1986, 41, 4945.

17. Varma, R.S.; Green Chem. 1999, 43; Larhed, M.; Moberg, C.; Hallberg, A.; Acc. Chem. Res. 2002, 35, 717.

18. Perreux, L.; Loupy, A. J.; Tetrahedron 2001, 57, 9199; Mayo, K.G.; Nearhoof, E.H.; Kiddle, J.J.; Org. Lett. 2002, 4, 1567.

19. Varma, R. S.; J. Heterocycl. Chem. 1999, 36, 1565.

20. Varma, R.S.; Kumar, D.; Org. Lett. 1999, 1, 697.

21. Patonay, T.; Varma, R.S.; Vass, A.; Levai, A.; Dudas, J.; Tetrahedron Lett. 2001, 42, 1403.

22. Varma, R.S.; Saini, R.K.; Synlett 1997, 857.

23. Seoane, G.; Pandolfi, E.; Gamenara, D.; Eicher, T.; J. Braz. Chem. Soc. 1996, 7, 307.

24. López, G.; Pandolfi, E.; Seoane, G.; Synthesis 2000, 10, 1403.

25. Varma, R.S.; Dahiya, R.; J. Org. Chem. 1998, 63, 8038.

26. Barboza, A.C.R.N.; Cruz, C.V.M.S.; Graziani, M.B.; Lorenzetti, M.C.F.; Sabadini, E.; Quim. Nova 2001, 24, 901.

Received: August 06, 2004 Published on the web: June 30, 2005 


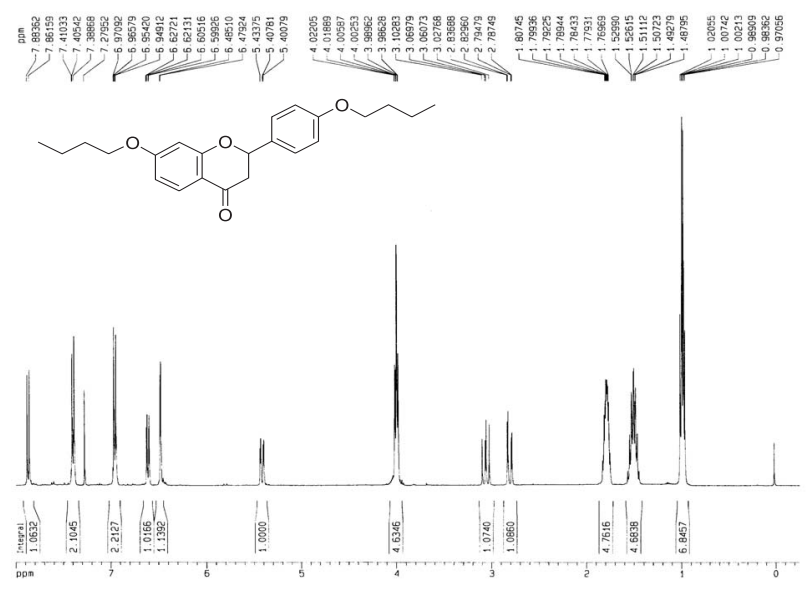

Figure S1. 'H NMR spectrum for 7,4'-dibutyloxyflavanone (compound 21)

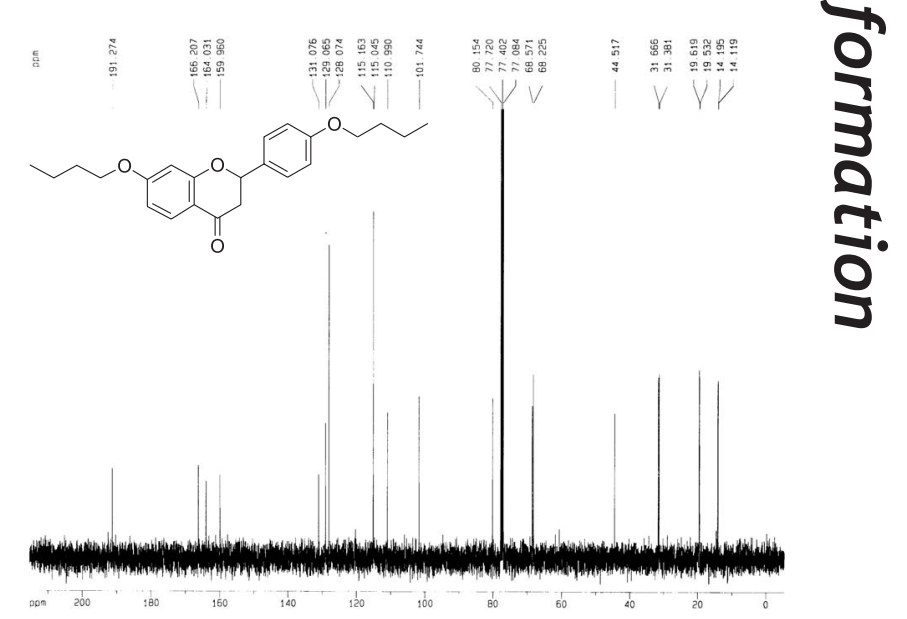

Figure S2. ${ }^{13} \mathrm{C}$ NMR spectrum for 7,4'-dibutyloxyflavanone (compound 2l)

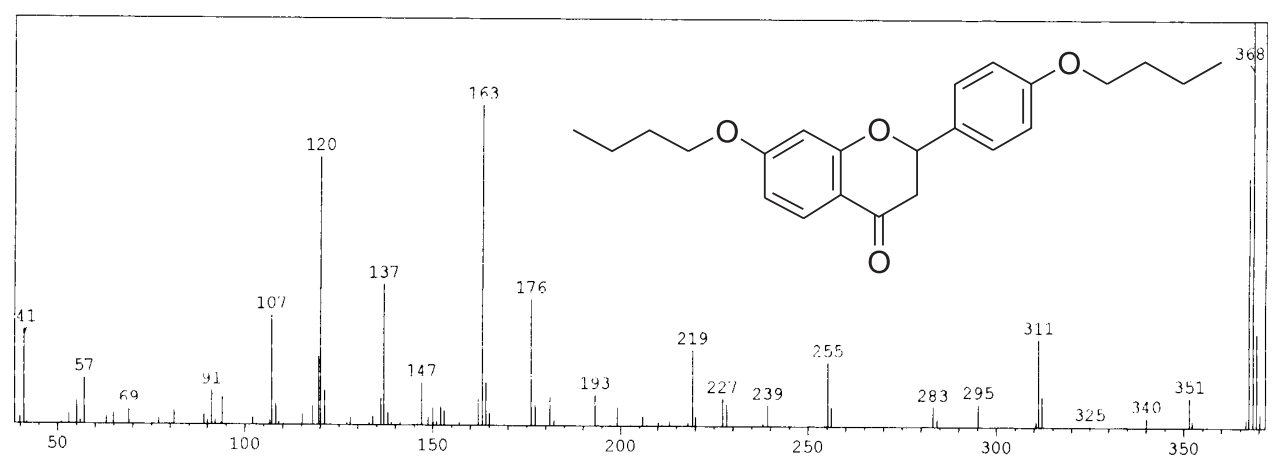

Figure S3. MS spectrum for 7,4'-dibutyloxyflavanone (compound 2l). 


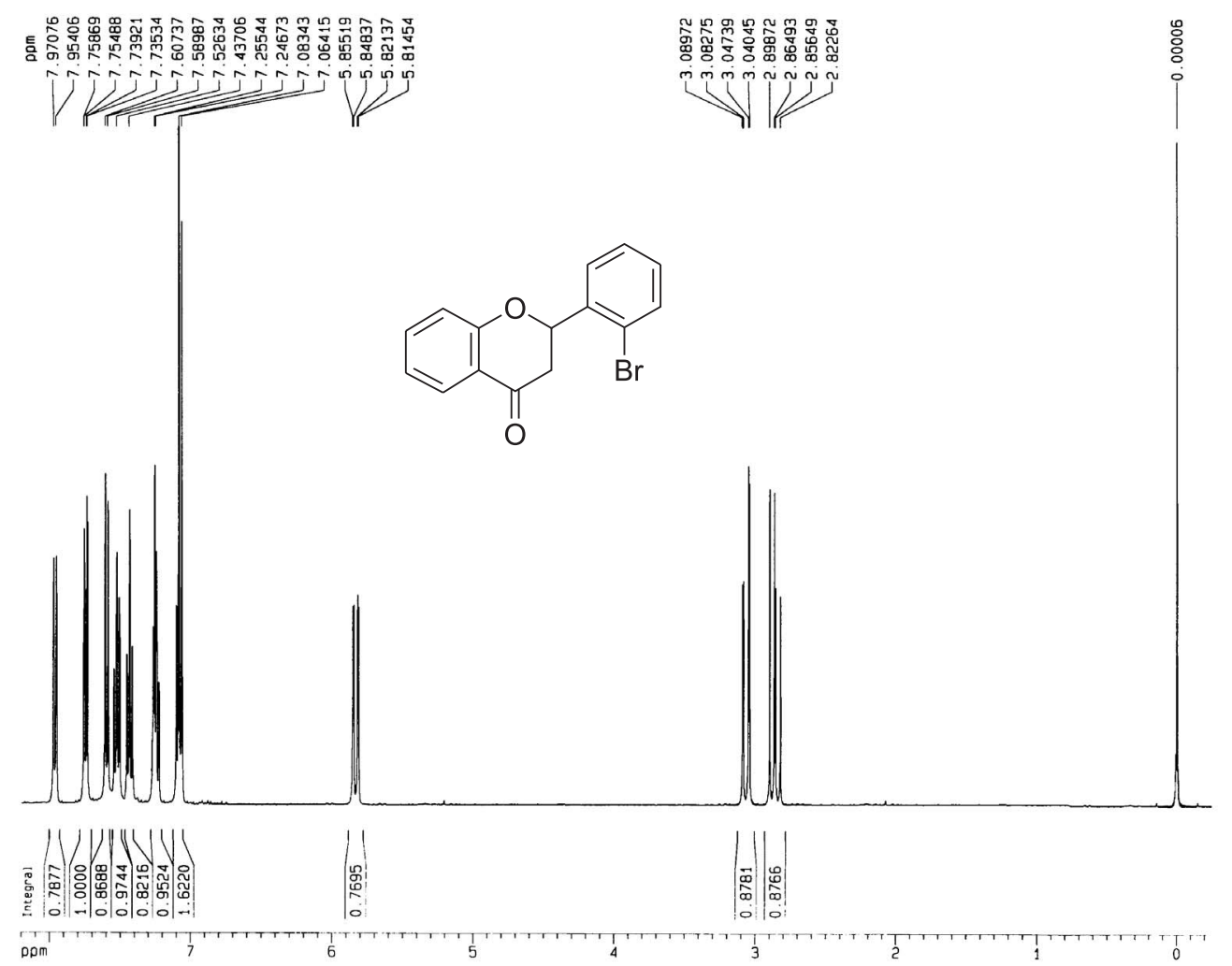

Figure S4. ${ }^{1} \mathrm{H}$ NMR spectrum for 2'-bromoflavanone (compound $\mathbf{2 m}$ ).

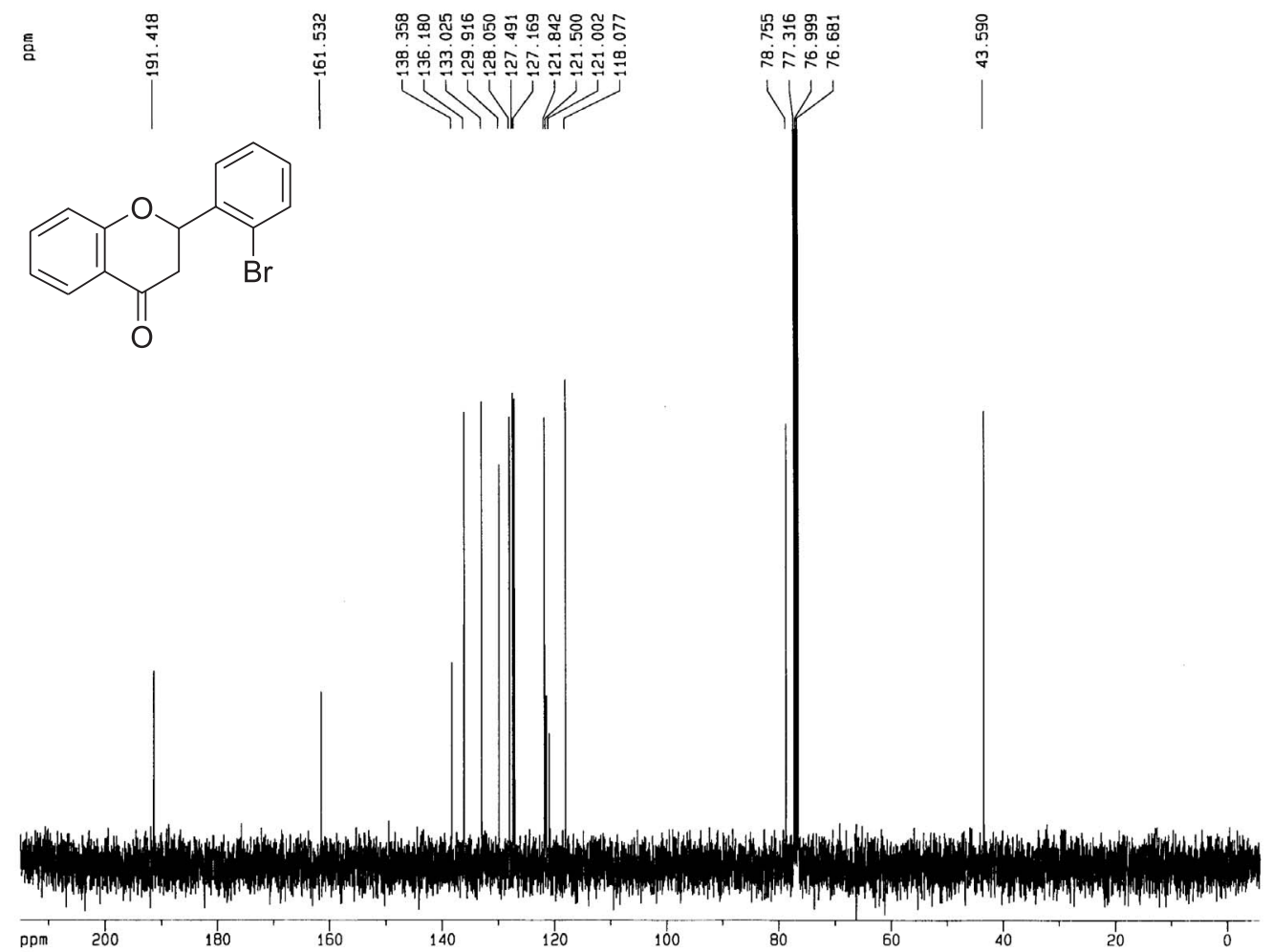

Figure S5. ${ }^{13} \mathrm{C}$ NMR spectrum for 2'-bromoflavanone (compound $2 \mathrm{~m}$ ). 


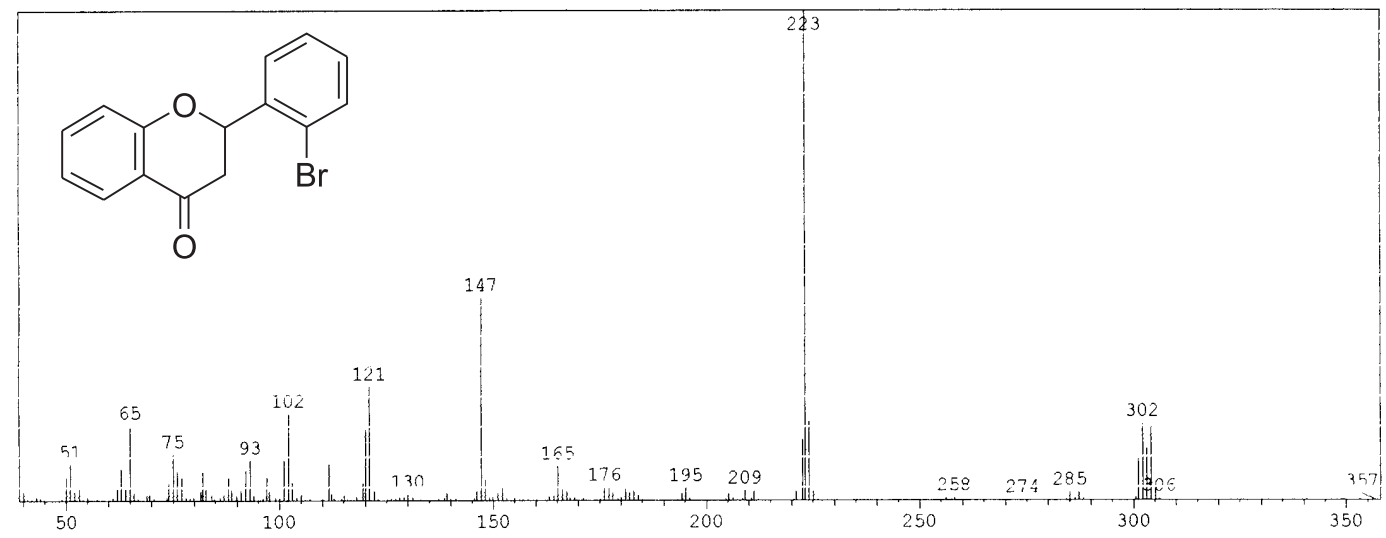

Figure S6. MS spectrum for 2'-bromoflavanone (compound $\mathbf{2 m}$ ).

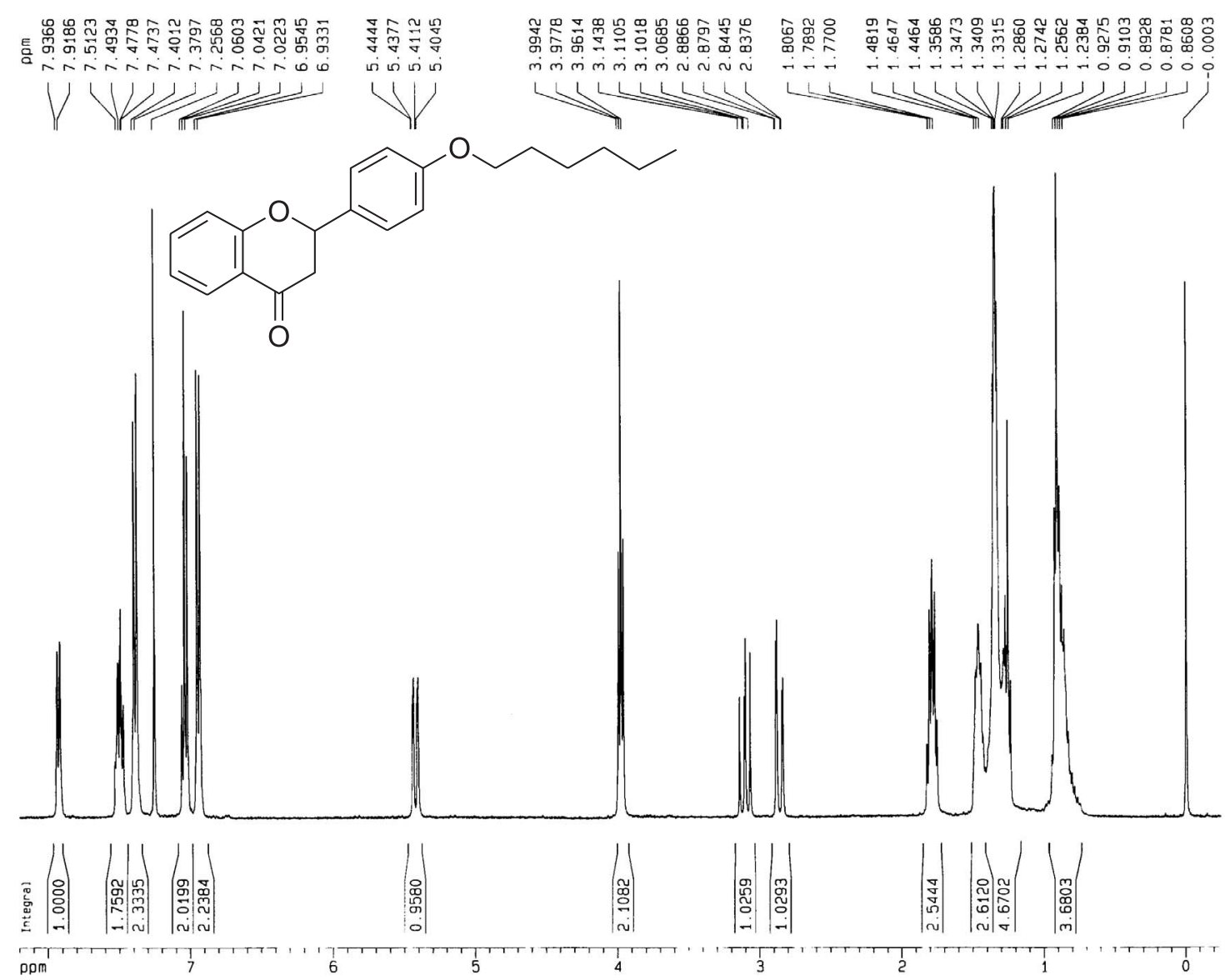

Figure S7. 'H NMR spectrum for 4'-hexyloxyflavanone (compound 2n). 


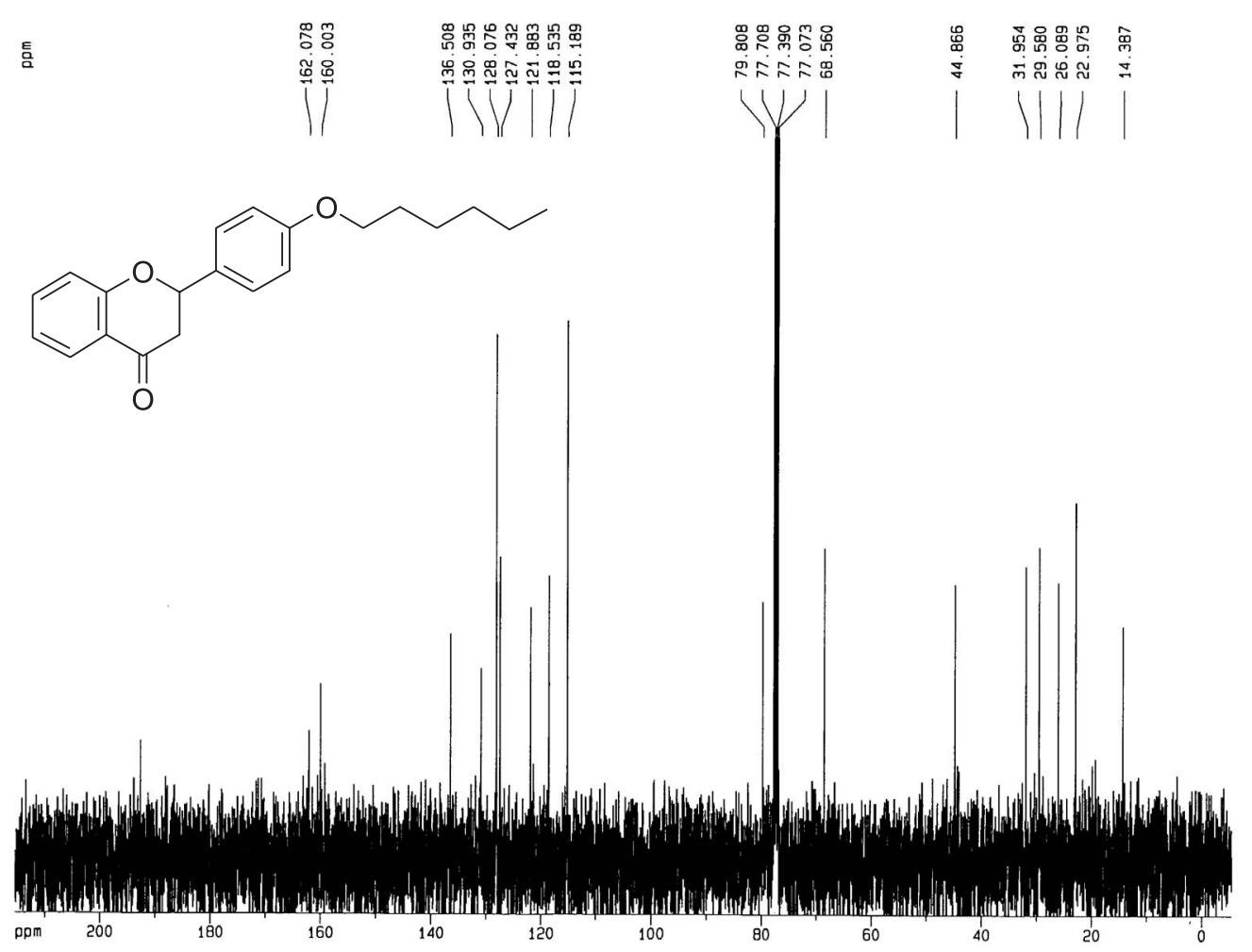

Figure S8. ${ }^{13} \mathrm{C}$ NMR spectrum for 4'-hexyloxyflavanone (compound $2 \mathbf{n}$ ).

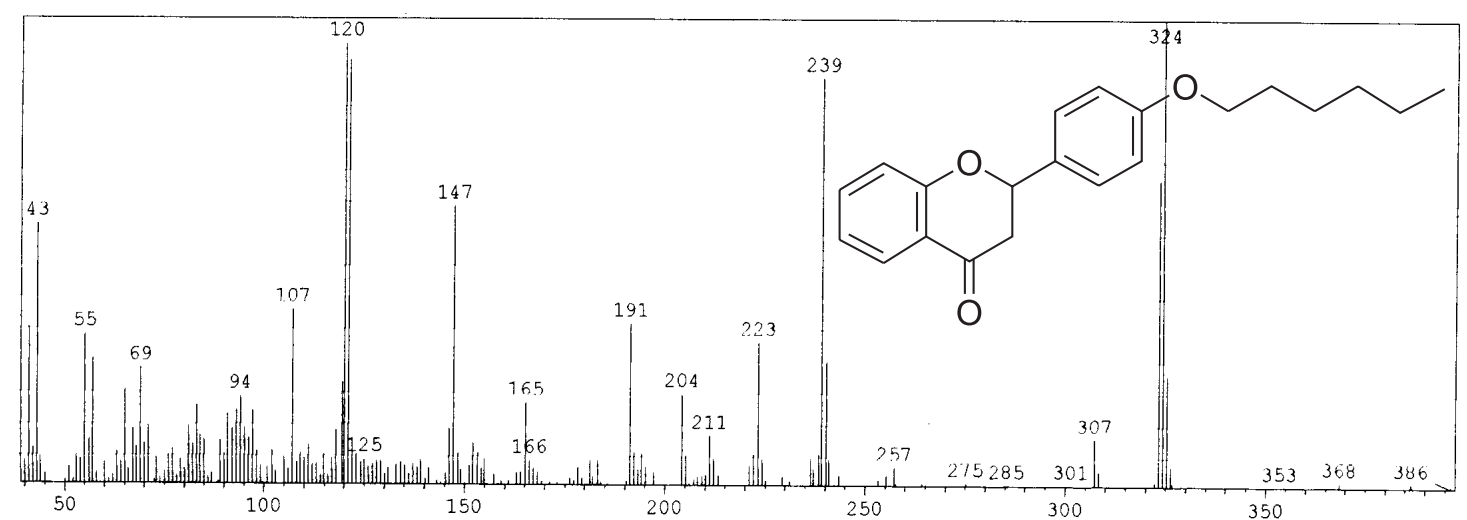

Figure S9. MS spectrum for 4'-hexyloxyflavanone (compound 2n). 


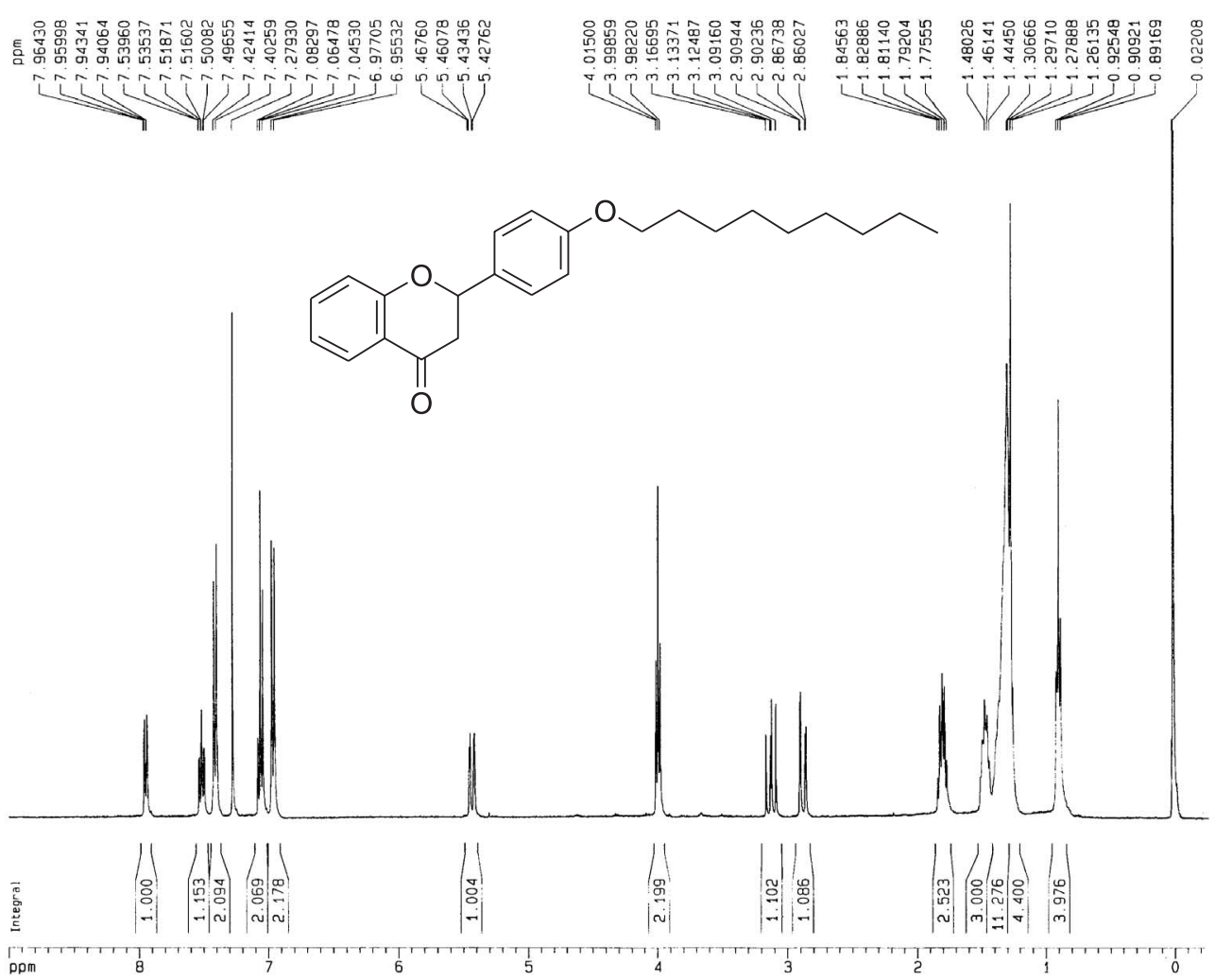

Figure S10. ${ }^{1} \mathrm{H}$ NMR spectrum for 4'-nonyloxyflavanone (compound 2o).

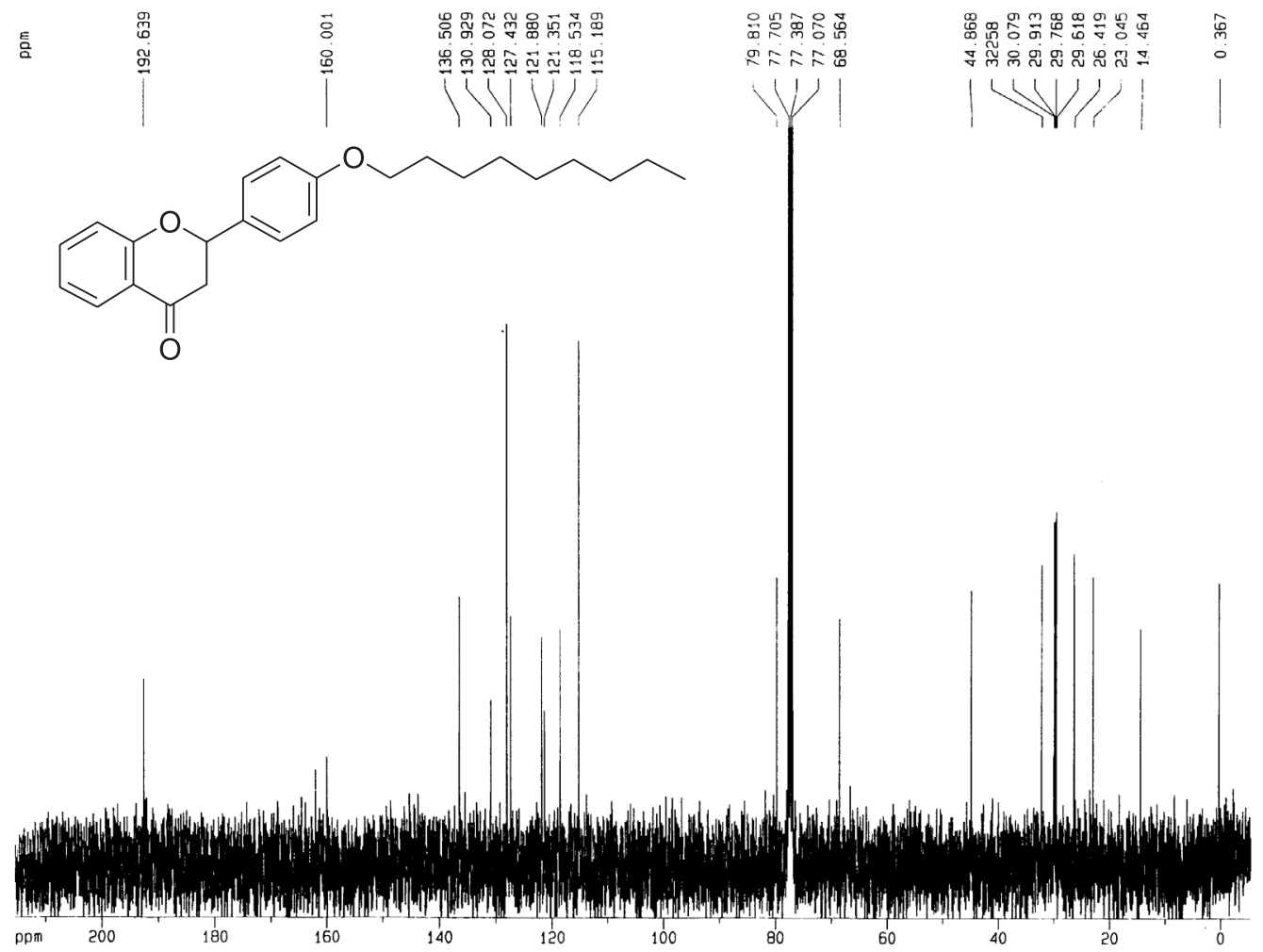

Figure S11. ${ }^{13} \mathrm{C}$ NMR spectrum for 4'-nonyloxyflavanone (compound 2o). 


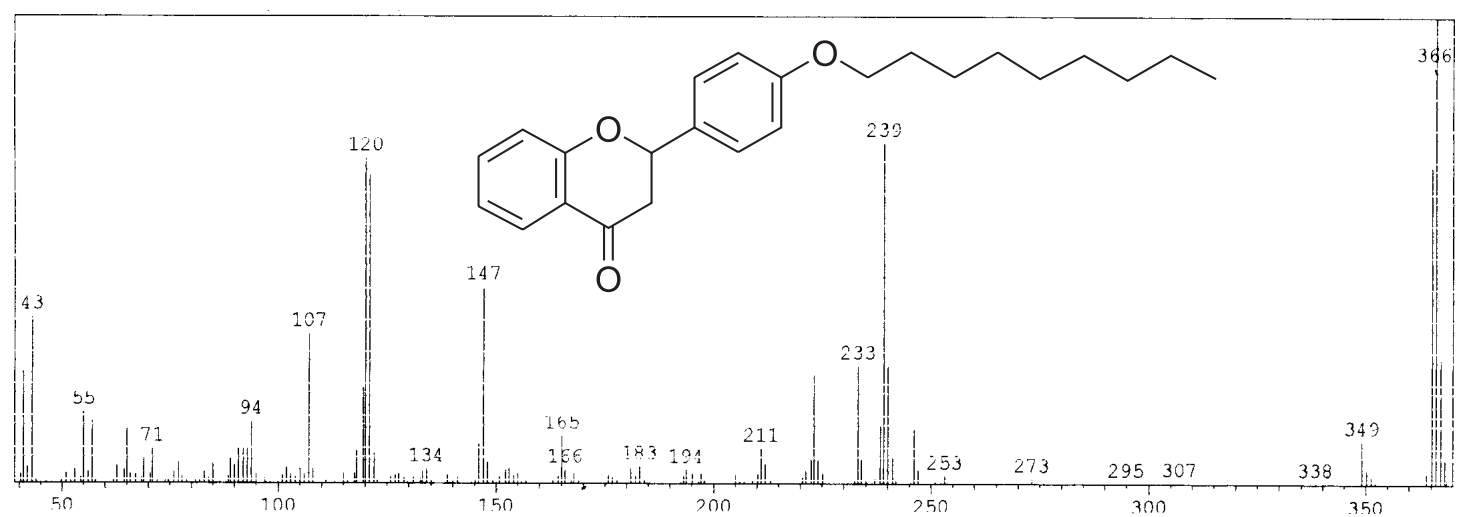

Figure S12. MS spectrum for 4'-nonyloxyflavanone (compound 2o).<smiles>COc1cc(OC)c2c(c1)OC(c1ccccc1Br)CC2=O</smiles>

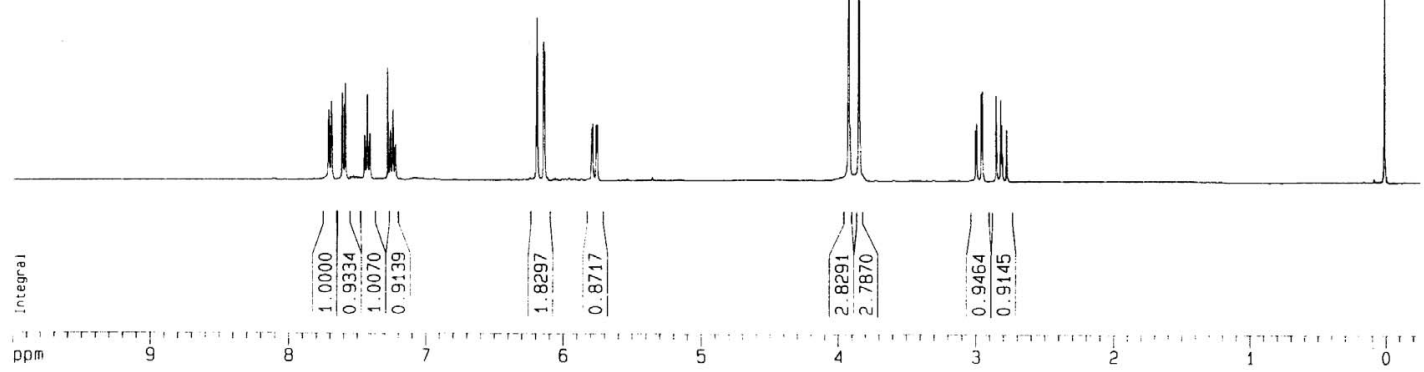

Figure S13. ${ }^{1} \mathrm{H}$ NMR spectrum for 5,7-dimethoxy-2'-bromoflavanone (compound 2p). 


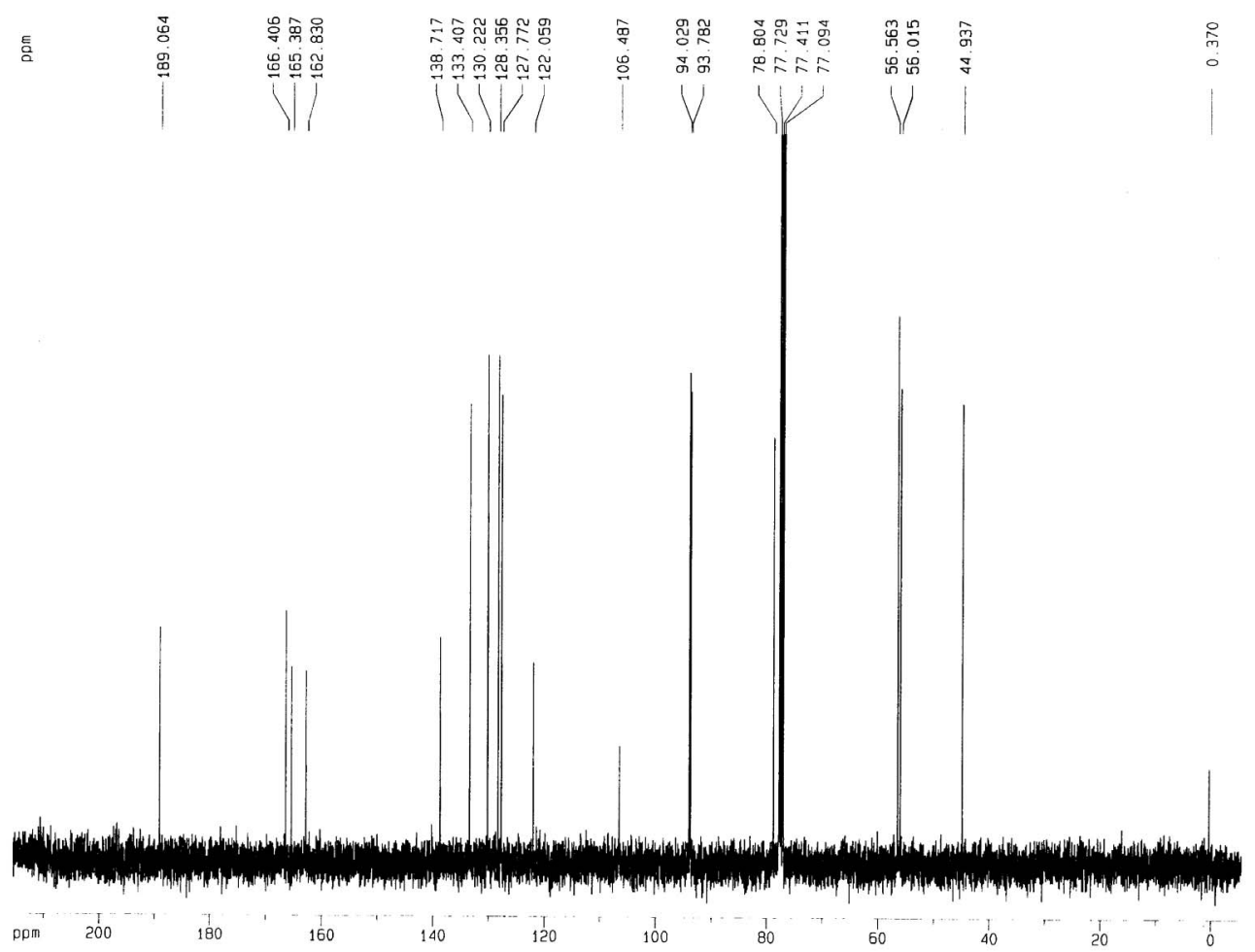

Figure S14. ${ }^{13} \mathrm{C}$ NMR spectrum for 5,7-dimethoxy-2'-bromoflavanone (compound 2p).

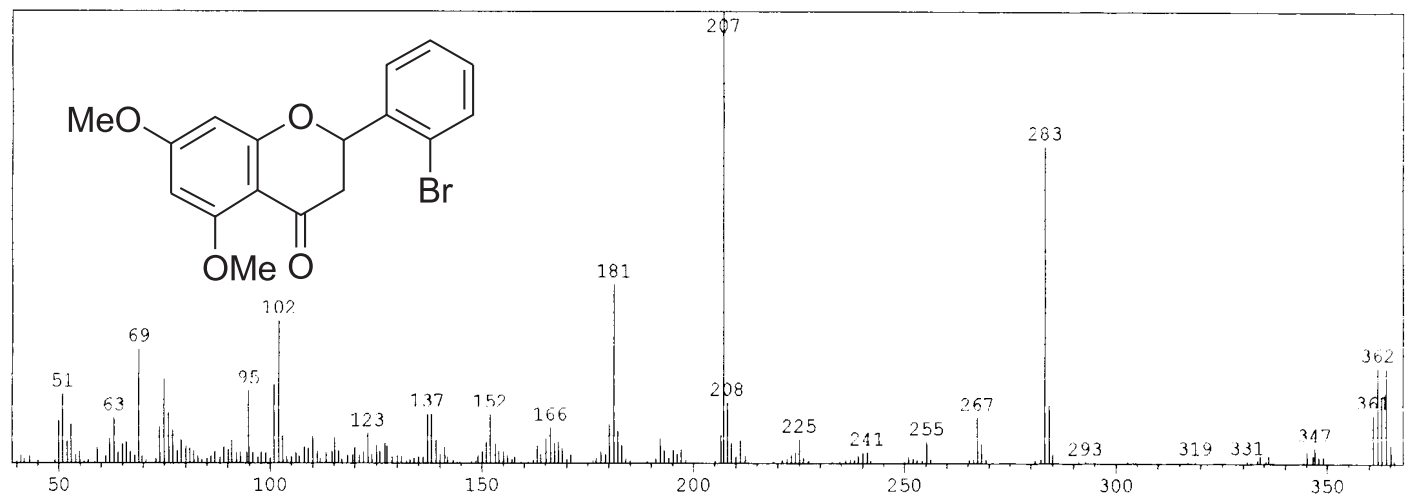

Figure S15. MS spectrum for 5,7-dimethoxy-2'-bromoflavanone (compound 2p). 